\title{
MULTI, INTER E TRANSDISCIPLINARIDADE - ONDE ESTAMOS E PARA ONDE VAMOS?
}

Ivan Domingues ${ }^{1}$

É com prazer que estou aqui em Ribeirão Preto para proferir a conferência de abertura deste VI Encontro de Pesquisa em Educação Ambiental, que está se iniciando hoje e que com certeza dará a vocês aqui presentes, provenientes de diferentes pontos do país, uma excelente oportunidade para trocas ciências e acadêmicas.

Quanto a mim, quando Vânia me fez o convite, eu confesso que meu primeiro impulso foi não aceitar, de um lado pelo fato de minha carreira não ser em ecologia nem em educação ambiental, de outro por não me sentir à vontade ou com as credenciais para falar do novo Plano Nacional de Pós-Graduação da CAPES, que ainda não tinha sido publicado. Depois de eu esboçar certa resistência, Vânia contra-argumentou, me convenceu e eis que eu estou aqui, hoje, diante de vocês.

O tema do qual eu vou tratar na conferência é a questão da multi, da inter e da transdisciplinaridade - onde estamos e para onde vamos? -, tema que recentemente eu abordei no Congresso da SBPC ocorrido no mês de julho em Goiânia e ao qual volto esta noite em Ribeirão para tratar dos mesmos assuntos, bem como de outros novos.

O mote que vai guiar as minhas reflexões são duas frases de Popper que aparecem em $\mathrm{O}$ universo aberto: um argumento pelo indeterminismo, publicado em 1982: "Eu não acredito em especialização e em especialistas. Ao emprestarmos demasiado respeito ao especialista, nós estamos destruindo a comunidade de aprendizagem, a tradição racionalista e a ciência ela mesma" (POPPER, Karl. The Open Universe: An Argument for Indeterminism. London: Hutchinson, 1982, p. 8).

Ao fazer esses comentários iniciais, de saída eu quero deixar claro que não sou especialista nesse campo do conhecimento e, como Popper, não julgo que deveria sê-lo ou que o expert deva ser reverenciado, tampouco tenho as respostas para as questões que vão transparecer ao longo de minha fala. Sou apenas um estudioso da matéria com frequentes incursões em seus diferentes aspectos, tendo já publicado livros e papers, assim como participado de inúmeros eventos e iniciativas com o propósito de discutir e difundir a transdisciplinaridade, mas sem nessas incursões ter aprofundado o assunto a ponto de me considerar um

\footnotetext{
${ }^{1}$ Professor titular da Universidade Federal de Minas Gerais. ,Brasil,domingues.ivan3@gmail.com
} 
expert. Sou apenas um curioso e o pouco que percorri ao tomar esse caminho me faz, como eu dizia, um estudioso. Um estudioso - acrescento eu agora - com uma gama variada de interesses, desde os interesses propriamente epistêmicos, em razão de minha formação de epistemólogo e de minha área de origem, filosofia, até os interesses ligados à política acadêmica e científica. Sinal desses interesses em política acadêmica e científica foi meu trabalho como assessor da CAPES com a função de ajudar na elaboração do PNPG 2011-2020, tendo entre outras coisas coordenado as discussões sobre a pós-graduação inter/multidisciplinar.

Voltando ao tema da conferência, eu gostaria de precisar que até recentemente eu procurei evitar me envolver, ao focalizar o multi, o inter e o transdisciplinar, nas questões relativas ao ensino, tendo-me concentrado exclusivamente na pesquisa. A razão era muito simples: como todo mundo sabe, o ensino é por demais conservador, ultradisciplinar, os departamentos funcionam como verdadeiros cartórios e há os problemas dos concursos e dos diplomas. Então, o terreno do ensino é pouco ou nada favorável a experiências extradisciplinares e à livre cooperação dos campos do conhecimento. Como disse a americana que ganhou em 2010 o prêmio Nobel de medicina: "O mundo tem problemas; as universidades, departamentos" - e eu acrescentaria: "Já os departamentos têm disciplinas e as disciplinas, os especialistas, verdadeiros guardas da cancela", e aí as coisas ficam difíceis, muito difíceis. Em contrapartida, por ser mais plástica e mais aberta a experimentações, inclusive a experimentos que fracassam e não levam a lugar algum, a pesquisa em princípio seria mais favorável e poderia abrir novos caminhos para o conhecimento. Com isso não quero dizer que a pesquisa e órgãos como o CNPq não sejam disciplinares. Em grande extensão são, sim, e muito; porém, a pesquisa é algo indeterminada e mais plástica, favorecendo experimentações e transgressões. A condição para se introduzir o trans ou o inter é simplesmente trocar o foco nas matérias e nas disciplinas, com suas fronteiras e demarcações, pelos temas e problemas, quaisquer que sejam eles, especialmente aqueles gerados fora do campo disciplinar, nas interseções das disciplinas e nas interfaces das diferentes áreas do conhecimento.

Foi com esse pensamento, com os olhos voltados para a pesquisa, que criamos na UFMG, em 1999, o IEAT. Precisamente, um Instituto de Estudos Avançados e Transdisciplinares, abarcando todas as áreas do conhecimento, e lá se foram 12 anos com o instituto se espraiando pela universidade, porém, restringindo-se à pesquisa, ontem, quando foi criado, e hoje, em suas diferentes frentes de atuação.

Mais recentemente, por ocasião da elaboração do Plano Nacional de PósGraduação 2011-2020, levada a cabo pela CAPES, eu tive de deixar minhas reservas de lado ao coordenar, como eu disse, os trabalhos sobre a pós-graduação multi e interdisciplinar. Vale dizer, ao coordenar os trabalhos em nível de 
assessoria técnica, com a participação de vários colegas das mais variadas áreas do conhecimento, inclusive de Arlindo Phillipi Jr., achei a experiência riquíssima, minha visão dos problemas viu-se profundamente matizada bem como alterada em importantes aspectos, e não foi sem convicção que recomendei uma especial ênfase nas ações da CAPES, no próximo decênio, tanto na criação de novos cursos quanto no adensamento de pós-graduações stricto sensu multi e interdisciplinares já existentes. Não sei se vocês sabem, o conjunto do documento foi aprovado pelo Conselho Superior da CAPES - inclusive a recomendação de priorizar a pós-graduação multi e inter -, foi sancionado pela Presidência da República como parte do Plano Nacional de Educação e foi recentemente publicado pela agência por ocasião da comemoração dos seus 60 anos. Quem quiser ter o documento de dois volumes, é só solicitar e será atendido. Meu sentimento, ao concluir esse trabalho, é que a área multi e interdisciplinar, que foi a que mais cresceu nos últimos tempos no sistema da CAPES, deverá crescer mais ainda nos próximos anos. E o que é importante: tendo vencido a barreira da criação e da quantidade ao conseguir uma considerável massa crítica e se espalhar por todos os pontos do país, o desafio maior agora será introduzir o crivo da excelência e vencer o desafio da qualidade - coisa que fatalmente vai acontecer, a julgar pelas iniciativas em curso.

Vou parando por aqui. Estou considerando essas coisas pessoais para dar a vocês uma ideia de onde eu venho, das minhas experiências sobre o assunto e dos meus interesses particulares. Continuo com reservas a respeito da transciplinaridade na área do ensino e não vejo maiores problemas em propor uma pós-graduação interdisciplinar, uma vez que a interdisciplinaridade já tem cidadania nos programas de pós-graduação mundo afora e na pós-graduação o ensino deve estar fundado na pesquisa. O que há de novo quanto à minha entrada pessoal é que ao longo desse tempo fui levado a trabalhar uma significativa literatura sobre a inter e a transdisciplinaridade, especialmente norteamericana, a qual me ajudou a me aprofundar na matéria e a firmar convicção a respeito da boa política nessa área do conhecimento.

Desse conjunto, deixando de lado outras referências importantes trabalhadas no passado, como o Manifesto da Transdisciplinaridade, de Basarab Nicolescu e Edgar Morin, eu destacaria:

KLEIN, Julie Thompson. Interdisciplinarity - History, Theory \& Practice. Detroit: Wayne State University, 1990.

KLEIN, Julie Thompson. Crossing Boundaries: Knowledge, Disciplinarities and Interdisciplinarities. Charlottesville: U. P. of Virginia, 1996.

KLEIN. Julie Thompson et al. (Ed.). Transdisciplinarity: Joint Problem Solving among Science, Technology and Society. Boston, Basel, Berlin: Birkhäuser Verlag, 2001. 
KLEIN, Julie Thompson. Interdisciplinarity and complexity: An Evolving Relationship. E:CO, v. 6, n. 1-2, p. 2-10, 2004.

NOWOTNY, Helga; SCOTT, Peter; GIBBONS, Michael. Mode 2 Revisited: The New Production of Knowledge. Minerva, 41, p. 179-194, 2003. (Printed in the Netherlands).

POMBO, Olga; GUIMARÃES, Henrique Manuel; LEVY, Teresa (Org.). Interdisciplinaridade: Antologia. Porto: Campo das Letras, 2006.

SOMMERVILLE, Margaret A.; RAPPORT, David (Org.). Transdisciplinarity: reCreating Integrated Knowledge (Advances in Sustainable Development). Oxford: EOLSS Publishers, 2000.

Dito isso, vou tratar da questão que nos foi proposta: multi, inter e trans onde estamos e para onde vamos? Para aplainar o terreno, vou propor algumas definições, provisórias e, como tais, sujeitas a revisões, coisa que eu considero normal, por não acreditar que o mundo caiba numa frase ou num conceito.

Por disciplina, à qual o multi, o inter e o transdisciplinar tacitamente se referem, entendo a matéria ou o campo do conhecimento, acepção já conhecida dos romanos, a exemplo de Cícero, ao se referir ao ensino, à educação e à ciência abarcando tanto a matéria ensinada quanto o método e o sistema ou a doutrina. A esses aspectos cognitivo e intelectual acresce um conjunto de acepções morais e mesmo políticas, também retidas pelos romanos ao tratarem da disciplina militar, da organização política e de aspectos da ética. $\mathrm{Na}$ era moderna, nas diferentes línguas, essas acepções são mantidas e ampliadas, como mostra o francês ao pôr em evidência as ideias de direção moral e de influência intelectual nas relações de discipulagem (Fénélon: “Demócrito, depois de ter permanecido por longo tempo sob a disciplina de Leucipo”), bem como de regra e de punição ao designar uma espécie de chicote (fouet em francês) usado para flagelar e se mortificar (coups de discipline ou simplesmente discipline, como encontrado em Molière). No plano cognitivo e intelectual, já em fins da Renascença, a noção se expande e passa a designar as diversas áreas do conhecimento, referindo-se às especialidades e às matérias que constituem a ciência, a filosofia e a arte. Quem quiser aprofundar este ponto, eu recomendo o artigo de Heinz Heckhausen intitulado "Disciplina e interdisciplinaridade" e publicado no livro organizado por Olga Pombo, Henrique Manuel Guimarães e Teresa Levy, ao qual eu me referi antes, no início de minha exposição. Lá vocês encontrarão um conjunto de critérios e características das disciplinas, como o domínio material, o nível de integração teórica, os métodos de análise, as aplicações práticas e a contingência histórica, ponto ao qual voltarei daqui a pouco (p. 79-84).

Quanto ao multi, ao inter e ao transdisciplinar, noções que têm ao centro a disciplina e que só fazem sentido se referidas a ela, está em jogo um fenômeno típico da modernidade tardia: a tentativa de aproximar os campos disciplinares e 
promover onde for possível a sua fusão. A julgar por Julie Thompson Klein (1990), já referida antes e considerada autoridade no assunto, as principais diferenças podem ser sumariadas assim: 1 - o multidisciplinar consiste na justaposição das disciplinas e sua natureza é essencialmente aditiva, não integrativa (p. 56): de fato, pode-se dizer, a justaposição é mais do que colocar lado a lado, pois o que é buscado é a aproximação das disciplinas e o compartilhamento das informações, como ocorreu nos laboratórios da Bell Telephone nos anos 1940, levando a importantes descobertas na área do transistor (ponto de contato, de acordo com Klein, p. 58); 2 - o interdisciplinar, por sua vez, consiste na cooperação das disciplinas, está fundado em genuínos grupos de trabalho (team work) e sua natureza é integrativa. Tal vem a ser a definição da Organização para a Cooperação e Desenvolvimento Econômico (OCDE), segundo a qual a interdisciplinaridade visa a mútua integração de conceitos, terminologias, métodos e dados em conjuntos mais vastos, repercutindo na organização do ensino e da pesquisa (p. 63). Os exemplos são inúmeros, com destaque para o projeto Apollo (p. 61), e são bastante diversificadas as vias para chegar lá: Piaget sublinhando a assimilação recíproca dos conhecimentos disciplinares, Alpert considerando o problema como a base fundamental da cooperação e Gusdorf acreditando que o team work é essencial (p. 63); 3 - por fim, o transdisciplinar, com ambição consideravelmente maior, consiste na tentativa de ir além das disciplinas (trans = além e através) e sua índole é transgressiva, levando à quebra das barreiras disciplinares e à desobediência às regras impostas pelas diferentes disciplinas. Assim, segundo Klein (1990), a transdisciplinaridade é mais "compreensiva em escopo e visão", tendo como objetivo fornecer sínteses teóricas abrangentes capazes de unificar o conhecimento, a exemplo da teoria dos sistemas, do neoevolucionismo, da complexidade, do behaviorismo, do estruturalismo e do marxismo. Além dessas teorias ou correntes de pensamento, não faltaram disciplinas, ou melhor, super ou supradisciplinas, candidatas ao posto, como a antropologia, a cibernética e a própria filosofia. Porém, diferentemente das experiências inter e multi, bem pesadas as coisas, não é possível ainda apontar experiências unificadoras trans bem-sucedidas, e de fato, mesmo em ações menos ambiciosas, as abordagens transdisciplinares são bastante raras (p. 68) devido à exigência de promover a dupla coordenação horizontal e vertical da pesquisa (p. 69). Trata-se, então, entre os partidários de um programa forte da transdisciplinaridade, mais de um novo paradigma do que de uma atitude, de um método ou de um olhar.

Penso que já é suficiente. O essencial é entender que o disciplinar, o multi, o inter e o trans são formas de organização e difusão do conhecimento e, como tais, não têm nada de necessário ou sacrossanto. De fato, são criações históricas e culturais e, enquanto tais, contingentes. Julie Klein (p. 71) observa sobre esse ponto que "não há uma inevitável progressão da 'multidisciplinaridade, passando pela 'interdisciplinaridade', até a 'transdisciplinaridade"'. Quanto à disciplina, 
Piaget em mais de uma ocasião sublinhou a artificialidade das barreiras das áreas do conhecimento, como as que separam a psicologia da biologia, e são conhecidas - acrescento eu - as circunstâncias em que foram criadas as disciplinas de metafísica, de obstetrícia e de sociologia: a metafísica é termo da linguagem corrente que era empregado pelos eruditos gregos para designar os livros de Aristóteles que estavam dispostos depois das obras de física (meta- + física); a sociologia era referente ao departamento em Harvard que tinha Sorokin como head, à diferença do departamento de "relações sociais", que ficou com Parsons, o qual vivia às turras com Sorokin; a obstetrícia era dividida em obstetrícia I e II, solução encontrada pela Universidade de Viena para acomodar os conflitos entre dois grupos de médicos que se digladiavam e ameaçavam o futuro da universidade.

Ainda sobre as circunstâncias em que foram formatadas as propostas inter e transdisciplinares, eu gostaria de precisar duas coisas. Sobre a interdisciplinaridade, o fato de que ela teve como a principal "promoter" a OCDE (Organização para a Cooperação e o Desenvolvimento Econômico), sediada em Paris e conhecida como clube dos ricos. Foi a OCDE que organizou em 1970, na cidade de Nice, França, um importante colóquio internacional sobre a interdisciplinaridade, cujas principais contribuições, Jean Piaget à frente, foram reunidas e publicadas mais tarde, em 1972, no livro seminal Interdisciplinarity: Problems of Teaching and Research in Universities [Interdisciplinaridade: problemas de ensino e pesquisa em universidades]. E foi também a OCDE que apoiou a realização, em 1975-1976, de um seminário pós-doutoral sobre a interdisciplinaridade na Universidade Estadual de Pennsylvania, nos Estados Unidos, o que resultou no segundo livro de referência da área, intitulado Interdisciplinarity and Higher Education [Interdisciplinaridade e ensino superior] e editado por Joseph Koklemans (1979). Em contrapartida, a transdisciplinaridade teve como principal patrocinadora a UNESCO, desde a realização de colóquios e congressos até o apoio a grupos de pesquisa. Em 1994 a UNESCO organizou o $1^{\circ}$ Congresso Mundial da Transdisciplinaridade, realizado em Arrábida, Portugal, o qual resultou na importante publicação intitulada Carta da Transdisciplinaridade, liderada por Basarab Nicolescu e Edgar Morin e com dezenas de signatários de diferentes partes do mundo, inclusive do Brasil. Mais tarde, em 1998, a divisão de Filosofia e Ética da UNESCO coorganizou o Colóquio sobre Transdisciplinaridade de Royaumont, uma bela abadia cisterciense que fica nas proximidades de Paris. Isso resultou no importante livro Transdisciplinarity: reCreating Integrated Knowledge [Transdisciplinaridade: reCriando conhecimento integrado], editado por Margaret A. Sommerville e David Rapport. Por fim, foi a vez do Colóquio de Zurich, em 2000, quando a UNESCO se associou à Swiss National Science Foundation [Fundação Nacional Suiça de Ciência], ao Swiss Federal Institute of Technology [Instituto Federal Suiço de Tecnologia], à Brown-Boveri etc. O livro Transdisciplinarity: Joint 
Problem Solving among Science, Technology and Society [Transdisciplinaridade: Resolvendo junto problemas entre ciência, tecnologia e sociedade] foi publicado um ano depois (2001), tendo Julie Klein como uma das editoras.

Esses eventos, que foram precedidos e seguidos por outros com propostas parecidas, inclusive no Brasil, em Vila Velha, ES, 2005, sem dúvida são da maior importância e ajudam o estudioso a compreender as coisas. Ao comparar as duas abordagens, descobrirá que Julie Klein, uma das estrelas da interdisciplinaridade e mundialmente conhecida graças a seus dois importantes livros, teve uma participação de proa nos Congressos da Transdisciplinaridade realizados em Zurich e em Royaumont, o que evidencia que não vem ao caso opor sem mais as duas perspectivas, sendo a clivagem em realidade uma falsa dicotomia e podendo a inter ser considerada amiga da transdisciplinaridade. A diferença é de escopo e de lastro, podendo a inter ser considerada mais instanciada e normalizada, ao passo que a trans é coisa de ciência pós-normal e pouco lastreada, segundo Julie Klein, mais uma promessa remetida ao futuro do que uma realidade efetiva. Assim, o lema que comandou as diretrizes da OCDE é a ideia segundo a qual "o interdisciplinar de hoje é o disciplinar de amanhã". Esse é o caso da bioquímica, por exemplo, interdisciplinar ontem e ciência normal e disciplinar hoje, no meio de outras tantas ciências disciplinares dentro e fora da biologia. Em contraste, Jean Piaget, ele mesmo uma das estrelas do primeiro congresso sobre a interdisciplinaridade, como eu já comentei, discrepava dessa divisa e propôs algo diferente: "O interdisciplinar de hoje é o transdisciplinar de amanhã", ou ao menos abre o caminho que nos leva até lá.

$\mathrm{Na}$ origem das duas experiências e mesmo da abordagem multidisciplinar, que de uma maneira ou de outra procura aproximar as disciplinas, está aquilo que os estudiosos chamam de inflação do conhecimento e pulverização da ciência numa infinidade de disciplinas, associadas à Babel das línguas e ao choque das duas culturas, de um lado a humanística, de outro a científica, que ignoram uma à outra e não falam a mesma linguagem. Essa situação de imenso desconforto foi produzida na metade do século XIX e foi agravada ao longo do século XX até chegar ao século XXI. Para se fazer uma ideia da situação em fins dos anos 1980, Julie Klein apresentou no Congresso Mundial sobre a Transdisciplinaridade, realizado em Arrábida, Portugal, em 1994, as cifras e voltou a elas num instigante artigo publicado em 2004 com o título "Interdisciplinarity and complexity: an envolving relationship" [Interdisciplinaridade e complexidade: uma relação envolvente]: 8.530 campos do conhecimento em 1987 e cerca de 4.000 disciplinas em 1990 (cf. p. 3). Na mesma época, num esforço de agrupar esse conjunto, o $\mathrm{CNPq}$ operava no Brasil com 868 áreas de especialidades, muitas vezes justapondo-as, e não exatamente integrando-as. Hoje, passados mais de 20 anos, os campos do conhecimento, assim como as disciplinas, com certeza aumentaram mais ainda e o próprio $\mathrm{CNPq}$ foi levado a tentar reagrupá-los mais de uma vez, como agora, ao encomendar a tarefa à CGEE, devendo o processo 
continuar indefinidamente. $\mathrm{O}$ resultado é o desconforto já experienciado à época de Chesterton, no início do século XX, levando-o a dizer, como lembrou Gusdorf, que "o especialista é aquele que sabe cada vez mais sobre um domínio cada vez mais restrito, de modo que a sua realização perfeita é saber tudo de nada" (POMBO; GUIMARÃES; LEVY, 2006, p. 19). Daí as tentativas de achar um remédio e vencer o mal-estar - verdadeira patologia no entender de muitos através da aproximação de disciplinas e da fusão de áreas do conhecimento.

Sobre esse ponto, o pendant entre dividir e agrupar parece estar relacionado tanto com a natureza da mente humana, que ao pensar e conhecer as coisas opera com a ajuda da análise e da síntese, quanto com a finitude da espécie humana e do aparelho perceptivo intelectual. Não podemos abraçar ou vislumbrar o todo, mas divisá-lo a partir de certa perspectiva, espacial e temporal, e, para percorrer um conjunto maior, demarcado e delimitado, devemos percorrer a parte. Não tem jeito: o conhecimento não está dado de antemão, trata-se de uma conquista e, como tal, depende das operações de análise e síntese. A pulverização do conhecimento em disciplinas e a divisão da ciência em áreas ou domínios têm a ver com isso: trata-se da análise. A análise é o modo como o conhecimento se inicia e a via que leva à ciência, justamente através de distinções, divisões e relações. Porém, o caminho da ciência não é contínuo e linear: para se poder avançar na caminhada, será preciso de tempos em tempos parar, retroceder e retomar os resultados, coligindo-os e sistematizando-os - operações da síntese, a qual, a bem da verdade, não é o contrário da análise ou o seu oposto, mas o seu avesso e complemento. Como dizia Bergson, o espírito de síntese não é senão o espírito de análise ampliado e desenvolvido. É aqui que reside o problema no meu modo de ver: as ciências modernas, ao chegarem à modernidade tardia, levaram as potências da análise a distâncias e a territórios nunca percorridos e avistados antes, mas, ao fazerem-no, não fizeram a viagem de volta para recolher e sistematizar os resultados e não ativaram as potências da síntese, de modo que só avistaram a parte e perderam de vista o todo. Ora, é justamente a visão do todo ou o sentido sinóptico das coisas, de que falava Platão, que a abordagem inter e mais ainda a transdisciplinar estão procurando estender à ciência.

Lévi-Strauss disse um dia, ao comparar sua mente de antropólogo com a do indígena primitivo, que ambos têm uma coisa em comum: ambos têm uma cabeça holística, ou melhor, "neolítica", como ele preferia. Um pouco essa é a situação de cada um de nós. Temos uma cabeça holística e sofremos da nostalgia do todo. Essa é também a situação do conhecimento. Contudo, o holos, o todo e o conjunto integram e abarcam as partes. Por seu turno, o conhecimento é uma conquista, conquista das partes e, também, do todo. O desafio hoje, depois de a ciência fazer a viagem de ida e conquistar territórios vastíssimos, arrancando-os da ignorância um a um e dispondo-os uns ao lado dos outros, é prosseguir a viagem, fazer a meia-volta e dar a visão do todo, visão perspectivada certamente, mas de conjunto, de alguma forma. 
Ao chegar a esse ponto, é hora de perguntar pelas conquistas e pelos resultados das abordagens multi, inter e transdisciplinares. Não é exagerado dizer que as conquistas são de perder de vista e tudo nos leva a acreditar que o cômputo aumentará mais ainda nos anos que virão. Para ficar com alguns poucos mas emblemáticos exemplos na área da pesquisa, podemos mencionar o projeto Manhattan, o programa do transistor da Bell Telephone e o Instituto Pasteur, de Paris, no campo multidisciplinar; o projeto Apollo, da Nasa, e a descoberta do DNA, no campo interdisciplinar, o primeiro contando com um clérigo no team work (porque sabia fazer boas perguntas) e o último, sem team work, mas obra de uma dupla, biólogo um (Watson) e físico o outro (Crick), que se apoiaram no trabalho de outra dupla rival, Maurice Wilkins e Rosalind Franklin, ele biofísico de formação e ela com sólidos conhecimentos de química: a decifração do DNA foi sem dúvida uma das maiores realizações da ciência do século XX; estava em jogo fundir a genética e a química, e a maioria dos biólogos ignorava a química e vice-versa; esse foi o caso de Watson, que era biólogo e zoologista, não sabia nem uma coisa nem outra e por isso teve de adquirir as duas - o exemplo de Watson e do DNA não é uma exceção, mas a ilustração de um mesmo modelo, e foi assim que um grande contingente de ciências hifenizadas foi criado no curso do século XX, como a bioquímica, a biofísica, a físico-química, a sociolinguística etc., espécies de joias da coroa da interdisciplinaridade e que depois perderam o hífen; já no campo transdisciplinar, o mais recente dos três, podem ser citados a teoria dos sistemas complexos, o Instituto de Santa Fé, na Califórnia, e as pesquisas em meio ambiente, cidades e saúde em diferentes cantos do planeta. Para além do trans, da pesquisa e dos megaprojetos, devem-se mencionar as experiências no ensino, ou melhor, nas universidades, e o que não faltaram e não faltam são projetos e iniciativas levados a cabo nas melhores universidades do mundo, podendo-se citar Harvard, Stanford, MIT, Berkeley, Columbia e Chicago, nos Estados Unidos, a Escola dos Anais, na França, o Centro de Epistemologia Genética, fundado por Piaget em Genebra (Suíça), e o programa Homem e Biosfera, da UNESCO, sediado em Paris, mas de alcance mundial. Quem quiser saber mais detalhes, no tocante a programas, instituições e linhas de pesquisa, poderá consultar os livros de Julie Klein: as informações são abundantes e convincentes (Ver p. ex. Interdisciplinarity - History, Theory \& Practice, p. 47-48, 49-51 e 169-172, onde se encontra um levantamento de instituições, programas de pós-graduação e revistas). Por fim, numa atmosfera de grande flutuação conceitual, uma vez que muito do que é dito da inter pode ser estendido à trans e vice-versa, o jornal Folha de São Paulo publicou recentemente uma matéria sobre a criação, em Harvard e no MIT, de laboratórios multi/inter/transdisciplinares voltados para a inovação tecnológica, desde aplicativos para celulares até campanhas para combater a malária na África (Harvard), e voltados para o combate ao câncer, a exemplo do Centro David H. Koch (MIT), cuja equipe conta no seu núcleo duro com psicólogos, cientistas, 
médicos e engenheiros especialistas em nanotecnologia (FSP, 13/06/11, Cotidiano, C5).

Essas conquistas e iniciativas são sem dúvida importantes, mas as dificuldades persistem, as disciplinas e as barreiras vão continuar existindo, fossos continuarão sendo cavados e junto com os obstáculos e os abismos haverá o incitamento à tentativa ou à necessidade de estabelecer pontes e superá-los. Mas não nos iludamos: não há e não haverá facilidades. Primeiro porque não há passagem direta do disciplinar ao multi, nem deste ao inter e ao transdisciplinar. A passagem deverá ser aberta e as pontes deverão ser erguidas a golpes de força. Há uma parábola indiana que nos ajuda a avaliar o estado de coisas e a situação do especialista, segundo Gusdorf. Ao retomá-la, digo que o contexto são os tempos antigos, e, trazido para os dias de hoje, o exemplo poderá parecer politicamente incorreto. Longe de mim, entretanto, querer censurá-la, e isso por entender que a mensagem é boa e tem um fundo de verdade. Trata-se da história de quatro cegos que se deparam com um elefante e tentam, ao apalpar diferentes partes de seu imenso corpo, compreender de que espécie de coisa elas são ou fazem parte. Assim, "cada um toca uma parte; um pretende que o elefante é uma folha muito grande, porque agarrou a orelha do animal; o outro que encontrou a pata pretende que o animal tem a forma de uma coluna; o ventre do animal faz pensar numa jarra bojuda e a tromba lembra uma grossa serpente". Gusdorf pensa que "tal como o cego do conto, o especialista toma a parte pelo todo, pronto a sustentar que o todo não existe ou é incognoscível" (POMBO; GUIMARÃES; LEVY, 2006, p. 48). A essa dificuldade soma-se o conservadorismo dos indivíduos e das instituições. Em pleno século XVII essa situação já inquietava Leibniz, meio desiludido da humanidade depois de anos e anos de luta em favor da unificação do conhecimento, e em vão: "O gênero humano, considerado na sua relação com as ciências que servem ao nosso bemestar, parece semelhante a uma multidão que marcha confusamente nas trevas sem ter nem chefe, nem ordem, nem palavra, nem outras marcas para regular a marcha e para se reconhecer. [...]. É fácil ver que o que mais nos poderia ajudar seria juntar os nossos trabalhos, partilhá-los com vantagem e regulá-los com ordem; mas, presentemente, o que acontece é que ninguém se arrisca ao que é difícil, ao que não foi ainda desbravado, e todos acorrem ao que os outros já fizeram, ou copiando-se entre si, ou combatendo-se eternamente" (LEIBNIZ, Die Phisophische Schriften, ed. Gerhardt, t. VII; apud GUSDORF, in: POMBO; GUIMARÃES; LEVY. 2006, p. 43-44). Não é exagerado dizer, com a escala e a profusão do conhecimento alcançadas nos dias de hoje, que a situação apontada por Leibniz se agravou mais ainda ao se ver acrescida dos males do "publish or perish", desconhecidos do filósofo e que se espalharam por toda parte, trancando os indivíduos nas disciplinas, tornando-os mais e mais conservadores e submetendo-os a um novo tipo de taylorismo: o taylorismo acadêmico ou intelectual. Por isso, mais do que treino ou adestramento, com vistas à aquisição 
de uma habilidade, a habilidade para tratar de grandes problemas e enfrentar megadesafios, a busca do novo e a disposição de abraçar a causa multi, inter e transdisciplinar exigirão um novo ethos e uma espécie de conversão moral. Todavia, o ethos da ciência e do intelectual está fraturado, depois de ser avassalado pelo mercado e pelo business, e deverá ser recomposto ou refeito. Essa é a situação. Mas como? Vou voltar a essa questão daqui a pouco.

Antes, porém, eu gostaria de comentar a última parte do título do colóquio: onde estamos e para onde vamos? Acho que já respondi: estamos no meio da confusão, sem saber ao certo para onde ir, com o ethos fraturado e pisando um terreno dominado pela disciplina, que veio para ficar e é uma das unidades do conhecimento, digo, da organização do conhecimento no ensino e da pesquisa, e que dá ensejo a tentativas de transgressão e superação, mas mantendo-a no core do conhecimento: simplesmente está em jogo o multi, o inter e o transdisciplinar, e não outra coisa, o anti ou o não disciplinar. Essa situação, em que a divisão do conhecimento em disciplinas e áreas guarda um paralelismo com a divisão do trabalho, parece ser impulsionada pela própria dinâmica do conhecimento, ao se ver às voltas com a necessidade de recortar o real, ainda que lhe aplicando os mesmos métodos e que a natureza da mente seja a mesma, como viu Descartes. Há, porém, um segundo fator que, a se acreditar em estudiosos como Julie Klein e Helga Nowotiny, parece atingir em cheio a abordagem transdisciplinar, e de resto bem mais do que as outras, a multi e a inter: trata-se do modo de produção de conhecimento de tipo II, que, diferentemente do tipo I, caracterizado por cindir conhecimento e sociedade e separar ética e ciência, ata aqueles dois, formata o conhecimento socialmente robusto e interpela pela responsabilidade individual e coletiva dos cientistas. Esse é o lado belo da coisa e de pronto reconhecido pelos partidários da transdisciplinaridade, como Julie Klein, Helga Nowotny e Michael Gibbons, que não hesitam em fazer do trans um dos traços fundamentais do modo II. Mas há outro lado, nada róseo e mesmo dark, uma vez que o apelo ao social e à responsabilidade coletiva do cientista vai junto com aquilo que Stratherm chamou de "terror da transparência", fundado na profusão dos ritos de verificação e controle típicos de uma sociedade auditada, que também se estenderam à sociedade do conhecimento.

Entendo que na raiz desse processo está o conhecido fenômeno da judicialização da política e seu avesso, a politização do judiciário, tendo como agentes os tribunais e os órgãos de controle, que, ao procurarem combater os vícios da confusão do público e do privado, levando os indivíduos, os políticos e os cientistas a privatizar o público, promoveram a publicização do privado e a anulação das diferenças das esferas do Estado, da sociedade e do indivíduo. Penso que a saída para essa excrescência do direito não está na ética utilitarista, ao procurar maximizar os ganhos e minimizar os danos, ao escolher o privado contra o público, mas na ética republicana, vale dizer, não na ética republicana tradicional, mas na ética republicana refundada, que, em vez de identificar o 
público com o Estado e a política, interpõe entre o indivíduo e o Estado, dilatando o público, a esfera mais ampla do social e do cultural.

É o que procurei mostrar em artigo publicado recentemente na França e que sairá em breve no Brasil, no qual eu trato do intelectual público, da ética republicana e da fratura do ethos da ciência.

Entendo que, se não é onde estamos e a realidade em que vivemos, é para onde deveríamos ir e a bela causa a exigir o melhor de nós, se quisermos atar ética, conhecimento e sociedade.

Muito obrigado.

\section{Referências}

KLEIN, Julie Thompson. Interdisciplinarity - History, Theory \& Practice. Detroit: Wayne State University, 1990.

KLEIN, Julie Thompson. Crossing Boundaries: Knowledge, Disciplinarities and Interdisciplinarities. Charlottesville: U. P. of Virginia, 1996.

KLEIN. Julie Thompson et al. (Ed.). Transdisciplinarity: Joint Problem Solving among Science, Technology and Society. Boston, Basel, Berlin: Birkhäuser Verlag, 2001.

KLEIN, Julie Thompson. Interdisciplinarity and complexity: An Evolving Relationship. E:CO, v. 6, n. 1-2, p. 2-10, 2004.

NOWOTNY, Helga; SCOTT, Peter; GIBBONS, Michael. Mode 2 Revisited: The New Production of Knowledge. Minerva, 41, p. 179-194, 2003. (Printed in the Netherlands).

POMBO, Olga; GUIMARÃES, Henrique Manuel; LEVY, Teresa (Org.). Interdisciplinaridade: Antologia. Porto: Campo das Letras, 2006.

SOMMERVILLE, Margaret A.; RAPPORT, David (Org.). Transdisciplinarity: reCreating Integrated Knowledge (Advances in Sustainable Development). Oxford: EOLSS Publishers, 2000.

\section{NOTAS}

1 - Inteligência

Alfred Binet: "A inteligência é o que eu meço com os meus testes".

2 - Enciclopédia: do grego "enkuklios paideia" = ensino circular/visão de conjunto.

Gusdorf: considerada a forma perfeita pelos gregos, a sua adoção indica a necessidade de os alunos fazerem a volta completa dos conhecimentos 
disponíveis e adquirir a visão do todo (cf. POMBO; GUIMARÃES; LEVY, 2006, p. 21).

Turgot: "No nosso século a filosofia, ou melhor, a razão, estendendo o seu império a todas as ciências, fez o que outrora fizeram as conquistas dos Romanos entre as nações: deitar abaixo as barreiras que faziam de cada ciência como que um Estado separado, independente relativamente aos outros" (apud GUSDORF, in: POMBO; GUIMARÃES; LEVY, 2006, p. 44) .

\section{3 - Interdisciplinaridade}

- John Polanyi, prêmio Nobel de química, 1986:

"Era como se os químicos fossem sociólogos, lidando com o comportamento de sociedades, e os físicos fossem psicólogos que apenas reconhecem as regras de comportamento dos indivíduos. Era evidente, nos cinquenta, que tinha chegado o tempo da convergência destes pontos de vista: se cada um, só por si, constituía um sistema de pensamento tão poderoso, uma vez combinados seriam ainda mais poderosos" (apud JORDAN, Trace, in: POMBO; GUIMARÃES; LEVY, 2006, p. 94).

- Gillian Humphries e Harden McConnell, biofísicos:

"[...] a dificuldade crescente com que se constroem fronteiras entre disciplinas científicas 'diferentes'. Este fenômeno não deve constituir surpresa, pois muitas destas fronteiras não são naturais, existindo apenas por conveniência de cientistas e bibliotecários. Se se permite que as fronteiras se tornem barreiras à ciência criativa, elas deixam de ser convenientes. Aqueles que se empenham em ciência interdisciplinar de ponta procuram habitualmente encontrar, não tanto especificidades, mas princípios unificadores" (apud JORDAN, Trace, in: POMBO; GUIMARÃES; LEVY, 2006, p. 94).

- Gerald Holton: themata unificadores.

- Holton distingue 3 tipos de themata interdisciplinares: 1 - conceito temático: simetria, continuum; 2 - themata metodológicos: busca de constâncias, leis, casos extremos; 3 - proposição temática ou hipótese temática (apud Jordan, Trace, in: POMBO; GUIMARÃES; LEVY, 2006 p. 96).

- Trace Jordan, na mesma linha, fala de tópicos integradores ou comuns: meio (aspectos químicos, físicos, biológicos e tecnológicos), visão (tratamento da luz, biologia e bioquímica do olho e psicologia da percepção), movimento (leis da mecânica, aerodinâmica física, fisiologia do movimento humano no desporto e na dança) (POMBO; GUIMARÃES; LEVY, 2006, p. 96, nota 10).

- Outro exemplo de Holton: tempo. 
- Holton: há uma mudança significativa na percepção do tempo no transcurso do século XX; desde Newton a física nos acostumou a ver no tempo uma variável absoluta, uniformemente fluente e independente; no curso do século XX passa a predominar a visão que torna o tempo uma variável descontínua e dependente de acontecimentos fortuitos; o resultado é a visão estocástica de um mundo abalado e possivelmente rejuvenescido por colisões e catástrofes (apud JORDAN, Trace, in: POMBO; GUIMARÃES; LEVY, 2006. p. 98).

- Prigogyne: "em todos os níveis, desde as partículas elementares à cosmologia, o aleatório e o irreversível desempenham um papel cada vez mais activo. A ciência é a redescoberta do tempo (PRIGOGYNE; STENGERS, 1974 apud JORDAN, Trace, in: POMBO; GUIMARÃES; LEVY, 2006, p. 98).

- Trace Jordan: "Não só a física mas também a química, a biologia e as ciências socais estão unidas pelo tema do tempo de Prigogyne, uma unificação ainda incipiente e apta a posteriores desenvolvimentos" (p. 99).

- Outro exemplo de tema: dualismo complementar / física quântica: Niels Bohr / biologia: Delbruck.

- Outro exemplo: propriedade emergente / física: superconditividade (p. 102) / acrescentar: química, biologia e sociologia.

- Holton: acredita que o número de themata em ciência é menos de 100.

- Trace Jordan: historicidade dos themata (p. 103, nota 19).

- Séc. XIX: tema da conservação / 1830-1850 / predominou em quase todas as disciplinas.

- Séc. XX: o tema do aleatório passa a prevalecer na biologia (evolução), na física (mecânica estatística) e nas ciências sociais (aplicação de métodos estatísticos).

- Trace Jordan: migração de conceitos e métodos.

- Da sociologia à física: segundo Porter, "a idéia de Mawell de aplicar a estatística à distribuição de velocidades moleculares derivou do uso desta nas ciências sociais" (p. 103, nota 19).

- Acrescentar: biologia e demografia / Darwin X Malthus.

- Exemplos de cursos temáticos interdisciplinares:

- Harvard: curso de física (Harvard Project Physics), coordenado por Holton, tendo como proposta explorar as ligações da física com outras disciplinas mediante uma abordagem histórica (p. 104).

- Berkeley: curso de Ciências Naturais Contemporâneas (física, biologia e química), organizado por Reif e voltado para alunos que não seguiam áreas científicas / educação científica geral / exploração de temas convergentes: aleatório (física térmica, difusão química e evolução biológica) + invariância (conservação da energia nos domínios orgânico e inorgânico) + uso de linguagem descritiva, com aplicações diversas (p. 106).

- Delattre: Inter / Níveis de realidade / Correspondências. 
- "Com efeito, a divisão em disciplinas resulta, em grande parte, do desmembramento da realidade a níveis de descrição diferentes".

- Inter: "Esforçar-se por estabelecer conexões entre as disciplinas é, portanto, e antes de mais, tentar precisar a correspondência entre estes níveis" (POMBO; GUIMARÃES; LEVY, 2006, p. 290).

- Watson fornece na sua autobiografia intelectual The double Helix o estado de espírito em que ele se encontrava antes de embarcar na aventura da descoberta do segredo do DNA, considerada a molécula de ouro e a chave da vida. A narrativa, mais do que uma análise psicológica do estado de alma do americano impetuoso, dá uma preciosa descrição do desafio interdisciplinar e do cruzamento de perspectivas e habilidades que levou nos anos cinquenta à fundação de um novo domínio da bioquímica: a genômica.

Comecemos pelos personagens e os principais atores: Wilkins (Kings College, Londres), Crick (Cambridge), Salvador Luria (o supervisor do $\mathrm{PhD}$ de Watson, italiano radicado nos EUA, onde atuou em várias universidades, como Columbia e o MIT), Delbruck (Caltech), Linus Pauling (do Caltech e de Stanford), prêmio Nobel de química, que havia descoberto a $\alpha$ hélice de certas proteínas, e Herman Kalckar, bioquímico com quem Watson fez seu pós-doutorado em Copenhagen. Estava no ar a ideia de que a chave do DNA se encontrava na química e Wilkins já vinha trabalhando a possibilidade de usar raio $\mathrm{X}$ para produzir as evidências da estrutura do DNA, contando para isso com a importante parceria de Rosalind Franklin, físico-química de formação e com conhecimentos profundos, teóricos e práticos, sobre o raio. Luria, o supervisor do $\mathrm{PhD}$ de Watson, acreditava que a chave do DNA poderia ser fornecida pelo estudo da estrutura química de um vírus (gene). Sabia-se naquela época que cerca da metade da massa de um vírus bacterial era DNA e a outra metade, proteína. Dos dois conjuntos, enquanto o conhecimento das propriedades químicas das proteínas era bastante sólido, era magro e incipiente o conhecimento acerca do DNA. A suspeita era que a estrutura química do DNA permitiria evidenciar como os genes duplicavam, mas ninguém tinha conseguido mostrar isso. E a explicação fornecida por Watson para esse semifracasso, ou melhor, para a dificuldade que pouco depois seria superada, parece convincente: nada menos do que a barreira disciplinar e aquilo que poderíamos chamar de cultura de áreas conformando o ethos e os interesses. Assim, de acordo com Watson, no período imediatamente anterior à descoberta da estrutura do DNA, entre 1945 e o início dos anos 1950, "apenas poucos químicos trabalhavam [o problema] e, exceto o fato de que os ácidos nucleicos eram verdadeiras moléculas grandes edificadas a partir de blocos menores, os nucleotídeos, não havia nada de químico que o geneticista poderia agarrar. Além disso, os químicos que poderiam trabalhar sobre o DNA eram quase sempre químicos orgânicos sem interesse em genética" (p. 30). Essa era a situação e a grande barreira: de um lado, geneticistas que não sabiam química; de outro, químicos que não sabiam genética - e o DNA 
esperando. Quanto a ele, Watson, também era vítima da situação: biólogo de formação, com pouca intimidade com a matemática, antes de se consagrar ao DNA, vivendo nos EUA, ele se "interessava principalmente por pássaros" e se esquivava de falar qualquer coisa ligada à física e à química, mesmo que apresentasse "dificuldade mediana". Segundo Watson, naquela época, os bioquímicos de Indiana the encorajaram a aprender química orgânica, mas depois de usar o "bico de Bunsen" para esquentar benzeno ele desistiu de estudar química (p. 28). Em consequência, foi preciso esperar mais alguns anos para que sua relação com a química tomasse outro rumo, e para isso a relação dele com Kalckar, o supervisor de seu pós-doutorado, foi sumamente importante. Kalckar era bioquímico e a brilhante exceção. Em 1945 ele trava contato com Delbrucks e Luria no Laboratory of Cold Spring Harbor, em Nova York, onde assistiu ao curso de Delbruck sobre vírus bacteriais. Dessa cooperação tornou-se possível mais tarde a combinação das técnicas de química e genética que iriam revolucionar a biologia (p. 30). Porém, tal iria ocorrer não em Copenhagen, na Dinamarca, como eles imaginavam, mas mais tarde, na Inglaterra, nos laboratórios de Wilkins no Kings College de Londres e de Cavendish em Cambridge, em 1953. Desses grandes personagens, Pauling ganhou o prêmio Nobel de química em 1954, enquanto Wilkins, Watson e Crick ganharam o prêmio Nobel de medicina em 1962. Se havia uma grande injustiçada nessa história ligada à descoberta da estrutura do DNA, da qual Pauling estava a um passo, esta sem dúvida foi Rosalind Franklin, que foi auxiliar de Wilkins em Londres, foi responsável pelas primeiras imagens em raio $\mathrm{X}$ da proteína famosa e morreu anos antes de câncer. 